\title{
Models for cost-offset community supported agriculture (CO-CSA) programs
}

\author{
Marilyn Sitaker, ${ }^{\text {* }}$ Mackenzie McCall b \\ The Evergreen State College \\ Weiwei Wang,c Mia Vaccaro, ${ }^{\mathrm{c}}$ \\ Jane M. Kolodinsky c \\ University of Vermont
}

Alice Ammerman d

University of North Carolina Chapel Hill

\author{
Karla Hanson ${ }^{\mathrm{f}}$ \\ Cornell University \\ Diane K. Smith $g$ \\ Washington State University Extension, Skagit \\ \& Whatcom County
}

Rebecca A. Seguin-Fowler h

Texas A\&M AgriLife Research

Stephanie Jilcott Pitts e

East Carolina University

Submitted October 2, 2020 / Revised January 23, February 20, March 10, and April 27, 2021 /

Accepted April 27, 2021 / Published online August 18, 2021

Citation: Sitaker, M., McCall, M., Wang, W., Vaccaro, M., Kolodinsky, J. M., Ammerman, A., Jilcott Pitts, S., Hanson, K., Smith, D., K, \& Seguin-Fowler, R. A. (2021). Models for cost-offset community supported agriculture (CO-CSA) programs. Journal of Agriculture, Food Systems, and Community Development, 10(4), 157-172. https://doi.org/10.5304/jafscd.2021.104.003

Copyright (C) 2021 by the Authors. Published by the Lyson Center for Civic Agriculture and Food Systems. Open access under CC-BY license.

\begin{abstract}
Cost-offset community supported agriculture (COCSA) appears to be a promising way to increase low-income households' access and intake of fresh

a* Corresponding author: Marilyn Sitaker, Ecological Agriculture and Food Systems, The Evergreen State College; 2700

Evergreen Parkway NW; Olympia, WA 98505 USA; +1-206395-7501; msitaker@gmail.com

b Ecological Agriculture and Food Systems, The Evergreen State College

${ }^{c}$ Center for Rural Studies, University of Vermont

d Department of Nutrition, Gillings School of Global Public Health and the Center for Health Promotion and Disease Prevention, UNC-Chapel Hill

e Department of Public Health, Brody School of Medicine, East Carolina University
\end{abstract}

produce, while also helping CSA farms expand their farm business. Yet single farms operating CO-CSAs may struggle to balance the demands of farming with CO-CSA program administration,

\footnotetext{
${ }^{f}$ Master of Public Health Program, Department of Population Medicine and Diagnostic Sciences, Cornell University

g Washington State University Extension, Skagit \& Whatcom County

h Department of Nutrition, Texas A\&M University System

\section{Funding Disclosure}

This material is based on work supported by the National Institute of Food and Agriculture, U.S. Department of Agriculture, under award number 2015-68001-23230. Any opinions, findings, conclusions, or recommendations expressed in this publication are those of the author(s) and do not necessarily reflect the view of the U.S. Department of Agriculture.
} 
funding, and recruitment. To address these challenges, CO-CSA programs operated by nonprofits have emerged, equipped with dedicated infrastructure, resources, and staffing. This study aims to describe organizational models and best practices of nonprofit CO-CSA programs, using a qualitative approach. We conducted interviews with five wellestablished nonprofit CO-CSA programs in the U.S. Administration of these five nonprofit COCSAs took several forms: (1) providing direct subsidies to individual CO-CSA member farms; (2) functioning themselves as an aggregator, packer, and distributor of regional produce; and (3) sourcing from an in-house farm incubator or food hub, then packing and coordinating delivery to pick-up sites. Nonprofit CO-CSA funding strategies included grants from federal and local government sources, private donations, fundraising, and grants. Marketing efforts occurred via social media, community events, and word of mouth. Both fundraising and recruitment were greatly facilitated by relationships with community partners. Having dedicated staff, as well as a community that values local agriculture and social justice, were identified as success factors. This descriptive, qualitative study systematically compares the attributes of five nonprofit CO-CSA programs. Future research should focus on identifying the cost-effectiveness of nonprofit COCSAs, compare the relative merits of single-farm and nonprofit CO-CSAs, and quantify the economic benefit of CO-CSA programs for farmers and local communities.

\section{Keywords}

Cost-Offset CSA, Entrepreneurship, Community Supported Agriculture, Supplemental Nutrition Assistance Program, Subsidized Direct-to-

Consumer

\section{Introduction}

Adequate fruit and vegetable (FV) intake, necessary for optimum health and lower risk of chronic disease (Aune et al., 2017; Carter et al., 2010; Wang et al., 2014), continues to be problematic in the United States (Krebs-Smith et al., 2010; Moore et al., 2015; Wilson et al., 2016). Those with lower incomes, who often reside in areas with limited access to produce, have a disproportionately lower prevalence of adequate $\mathrm{FV}$ consumption (Grimm et al., 2012; Kamphuis et al., 2006). To increase FV consumption and boost farm revenue, the U.S. Department of Agriculture (USDA) provides grant funding to promote sales of locally grown foods at direct-to-consumer (DTC) venues (USDA, 2016). Although this approach has demonstrated some success (Allen et al.,2017; Minaker et al., 2014; Vasquez et al., 2016), disparities in access and financial resources put DTC venues out of reach for many low-income households (LIHH) (Galt et al., 2017; Vasquez et al., 2017). Both the acceptance of Supplemental Nutrition Assistance Program (SNAP) benefits at DTC venues, and programs that provide a dollar match when SNAP benefits are used, help reduce financial barriers for lowincome consumers and improve FV intake (Dimitri et al., 2015; Durward et al., 2019; Olsho et al., 2015; Young et al., 2013).

For community supported agriculture (CSA), a DTC model in which consumers pay for a "share" of a local farm's crops at the beginning of the season in return for a weekly (or biweekly) portion of the harvest, farms offer additional ways to reduce financial barriers. These include payment plans, working shares, low-cost shares, transportation assistance, bartering, and cost-offset programs (Forbes \& Harmon, 2008). In a cost-offset CSA (CO-CSA), low-income subscribers pay a portion of the cost in installments throughout the harvest season, with the remainder paid through other funding sources at the beginning of the season (Sitaker et al., 2020a).

The CO-CSA appears to be an appealing strategy for farmers who want their CSA to be accessible to consumers of all income levels (Calancie et al., 2015; Khan et al., 2009; SeguinFowler et al., 2020). In California, 25\% of farms said they used strategies to address the financial constraints of LIHH, including CO-CSAs that were funded through donations (25\%), sliding scale $(8.3 \%)$, fundraising $(5.6 \%)$, or workshares $(5.6 \%)$ (Guthman et al., 2006). A recent national survey of CSA managers found that $14.4 \%$ of 495 farms interviewed nationwide had cost-offset voucher programs for LIHH; an additional $67.7 \%$ expressed interest in coordinating with other pro- 
ducers to adopt a similar program (Woods, Ernst \& Tropp, 2017). Several toolkits have been developed with advice on how to start or run CO-CSA programs for LIHH (Sitaker et al., 2020b).

Like other programs that promote locally grown foods, CO-CSAs have the potential to tap into a new market segment, thus expanding CSA farms' customer base at a time when DTC growth has plateaued (Low \& Vogel, 2011; Sitaker et al., 2019; 2020a). The financial benefits of the COCSA model for farmers have yet to be quantified; only one study has documented start-up costs and potential profitability of a CO-CSA in quantitative terms (Cohen \& Derryk, 2011). However, other studies have described benefits that are nonmonetary, as well as those that could be considered as precursors to increased farm revenue. For example, many farmers reported that offering a CO-CSA helped them meet the social justice component of their mission, expand their membership, and add to farm income (Abbott, 2014; Andreatta et al., 2008; Cohen \& Derryk, 2011, Seguin-Fowler et al., 2020; Sitaker et al., 2020a; 2020b). However, some were challenged by the time it took to collect and record weekly payments and follow up on missed payments and pick-ups (Hoffman et al., 2012; Sitaker et al., 2020a, 2020b). Additionally, many independent farms wanting to start a CO-CSA, or continue one after study funding ended, expressed concerns about the time, labor, and skill it would require to raise funds, recruit low-income members, and administer the CO-CSA going forward (Quandt et al., 2013; Sitaker et al., 2020b).

CO-CSA programs operated by nonprofits are positioned to address these challenges in several ways. While single-farm CO-CSAs may experience conflicts between the demands of farming and program administration, nonprofit CO-CSAs have the advantage of organizational infrastructure and dedicated staff who have expertise in fundraising, program management, and marketing (Cohen \& Derryk, 2011; Woods et al., 2017). They have the bandwidth to develop the necessary community partnerships for outreach to LIHH and help with ancillary nutrition education programming (Cohen \& Derryk, 2011). Further, nonprofit CO-CSAs may be sourced by multiple farms or by one or more food hubs, thereby allowing the program to serve more LIHH in a wider geographic area (Sitaker et al., 2020c).

CO-CSAs are a promising strategy for increasing LIHH's FV intake (Seguin-Fowler et al., 2020), yet single farms might find it challenging to operate a CO-CSA on their own. Nonprofits with dedicated staff and resources to run the program may be better positioned to handle the challenges that single-farm CO-CSAs face in finding funding, recruiting, and administering the program. Yet, to date, only two studies have reported on the organizational characteristics of long-standing CO-CSAs operated by nonprofits: Corbin Hill Road (Cohen \& Derryk, 2011) and Fair Share (Woods et al., 2017). This study systematically explores the various ways that nonprofit CO-CSAs are structured and identifies their preferred practices for CO-CSA administration, financial operations, logistics, partnership development, and marketing. We conducted interviews with directors and managers of five nonprofit organizations that operate CO-CSAs in geographically diverse parts of the U.S. Findings from this study may prove useful for researchers interested in conducting further research on COCSAs, as well as farmers, nonprofits, and policymakers interested in starting or supporting a nonprofit CO-CSA in their community.

\section{Methods}

In 2019, we conducted five semi-structured interviews with nonprofit organizations that operated CO-CSA programs, using a structured interview guide (Appendix A) that included the following topics: organizational description, CO-CSA operations, cost-offset and other accommodations, funding sources, marketing, and logistics. From a compiled list of CO-CSAs (Sitaker et al., 2020c), we purposively selected five nonprofit organizations from three out of four regions of the U.S. that had been in operation for at least 4 years and had diverse operating models. Two of these wellestablished programs had previously been featured in published studies and were included so that we could compare consistent, updated information across all five nonprofit organizations. Another one of the five CO-CSA programs was no longer active, but was included because it featured a unique network of community partnerships. We 
sent an email invitation to either the director or manager of each CO-CSA program, describing the purpose of the study, the interview format, and the discussion topics. All five agreed to participate and, subsequently, one-hour telephone interviews took place in February and March 2019. Each nonprofit was compensated US $\$ 50$. The study protocol was approved by the institutional review boards at the University of Vermont (protocol ID \# 180204) and Cornell University (protocol ID \#1501005266) and informed consent was obtained verbally prior to data collection.

The semi-structured interviews were recorded, transcribed verbatim, and imported into NVivo version 11 (QSR International). Three analysts (M.S., W.W., and M.V.) met to review one transcript and develop initial themes and subthemes across all question categories. One analyst (M.V.) then coded a second transcript, which was reviewed and discussed with the two other analysts. Once consensus was reached, a codebook was generated and used to guide the coding of the remaining interviews. Once all five interviews had been coded (by M.V.), a second analyst (M.S.) double-coded three transcripts, and both analysts met to discuss and resolve discrepancies.

Qualitative findings were grouped into the following general categories: (a) organizational description, (b) CO-CSA operational structure, (c) cost-offset and other accommodations, (d) funding sources, (e) outreach and marketing, and (f) logistics, payments, and pick-ups. We describe the role of community partners with regard to CO-CSA funding and marketing efforts. We also report on the facilitators and challenges of operating a COCSA program that were identified by nonprofits and their advice for starting a CO-CSA program.

\section{Results}

\section{Organization Description}

All five CO-CSAs in this study were programs of nonprofit organizations that aim to create a just and equitable food system and address food inequities and gaps in their local food economies. Each organization used a variety of strategies to accomplish its mission in addition to the CO-CSA.

Nonprofit A (New York), created in 2009, is a social enterprise dedicated to supplying "fresh food to those who need it most." This is achieved primarily through wholesale produce delivery and the CO-CSA program started in 2018. Produce is sourced from four major food hubs that work with around 200 growers. In addition to affordable prices, Nonprofit A offers flexible sign-up and payment options.

Nonprofit B (Maine) began as a training farm in 2001, providing income and skills development to help growers become independent farmers. Produce grown by trainees is distributed through the CO-CSA by the nonprofit's food hub, which began in 2010. The food hub also sells through wholesale channels and raises funds to buy farmers' leftover end-of-season crops for donation to food pantries. Nonprofit B operates a youth leadership program in which high school students can learn about food systems and participate in various urban farming and cooking projects. It also offers youth programming in school classrooms and works with school gardens in the Portland area.

Nonprofit C (Wisconsin) was created in 1992 to connect people with local farms. Nonprofit C offers farmer training and education on such topics as marketing and promotional support, on-site CSA support, and CSA promotion. Its CO-CSA program, sourced by farms in the Nonprofit $\mathrm{C}$ coalition, has been working to make it easier for LIHH to purchase a CSA since 1996.

Nonprofit D (California) is an urban organization founded in 2007 focused on equity and racial justice that seeks to improve health and employment opportunities in low-income communities of color. It does this by distributing produce, creating edible parks and plazas, holding youth and community education programs, and fostering small foodbusiness incubation. Nonprofit D offers a kitchen incubator program, youth entrepreneurship programs, and youth gardening and fellowship programs. Its CO-CSA program, in operation since 2009, features produce sourced through Nonprofit D's food hub.

Nonprofit E (Massachusetts), started in 1991, is a youth development organization focused on food production and distribution that provides support for gardening, community organizing, and food system planning. Nonprofit E employed 25 
full-time staff, with additional help from over 100 youth employees and 2,000 volunteers. It operated five farms that produce over 250,000 pounds $(113,000 \mathrm{~kg})$ of chemical- and pesticide-free food each season for a charitable donation, cost-offset sale at farmers markets, and youth-driven food enterprises. Nonprofit E's CO-CSA program was in operation from 2012 to 2015.

\section{CO-CS A Operations and Logistics}

Nonprofit directors and managers described various structures in characterizing their CO-CSA program: providing direct subsidies to individual member farms for their CO-CSA programs (Nonprofit $\mathrm{C}$ ); purchasing food from multiple food hubs and arranging deliveries to pick-up sites where members pack their own boxes (Nonprofit A); functioning as a food hub that aggregates food from multiple independent farms, then packs and delivers CO-CSA shares to pick-up sites (Nonprofit D); and sourcing from farming projects within the organization, and packing and coordinating delivery to CO-CSA pick-up sites (Nonprofit B and Nonprofit E). Table B1 in Appendix $B$ provides detailed information on the logistical arrangements for each nonprofit.

Almost every manager or director expressed appreciation for the important role played by COCSA pick-up site hosts, which included community volunteers (Nonprofit D), an apartment complex (Nonprofit B), and Head Start centers (Nonprofit E). For Nonprofit E, Head Start also facilitated recruitment and enrollment.

\section{Membership Size, Subsidies, and Accommodations}

The number of cost-offset shares provided in 2018 ranged from 43 to 1,065 (Table 1). Between 2012 and 2015, Nonprofit E said its CO-CSA had "high turnover," with shareholders dropping out in the middle of the season. However, drop-outs were replaced with other LIHH that had signed up to a waitlist, so there was no net loss of customers. Nonprofit D reported a high rate of CO-CSA retention (75\%), while nonprofits $\mathrm{B}$ and $\mathrm{C}$ reported lower retention rates $(50 \%$ and $30 \%-50 \%$, respectively).

CO-CSA subsidies ranged from $40 \%$ to $100 \%$ of the market share price (Table 1), with some offering multiple cost-offset levels, depending on need. For example, Nonprofit B offered a free share (100\% cost-offset) to 28 asylum-seekers. Nonprofit A offered a US $\$ 10 /$ week share to 83 SNAP-EBT users, while 42 other individuals paid US $\$ 20$ /week for a "social impact share," which allowed Nonprofit A to offer more lower-cost shares. Since the production costs for these shares were between US $\$ 25$ and US $\$ 35$, Nonprofit A cost-offset all shares internally to some degree.

Most nonprofits instituted formal eligibility criteria for CO-CSA membership, such as current participation in SNAP-EBT or self-reported income at or below $185 \%$ of the federal poverty level (Table 1). One offered CO-CSA shares to LIHH with children attending Head Start, including parents residing in a women's shelter that had a daycare center.

All allowed weekly installment payments without requiring an upfront deposit and accepted SNAP/EBT. Nonprofit A and Nonprofit D allowed payments in advance. Other accommodations included having bilingual staff and offering bilingual newsletters and application forms (Table 1). In addition to the newsletters, recipes, and blogs, nonprofits held cooking classes and demonstrations, or had done so in the past. Some farms in Nonprofit C's CSA Coalition offered market-style selection; Nonprofit B tailored the contents of its Asylum Share to be more culturally appropriate.

\section{Funding Sources}

Nonprofits used multiple strategies to fund the CO-CSA (Table 2). Community partners often helped nonprofits find funding support. For example, one community organization facilitated a market-match grant so that Nonprofit D could offer a $50 \%$ cost offset to members with EBT benefits. Similarly, a co-op retailer provided a grant to support Nonprofit C's CO-CSA program.

\section{Outreach and Marketing}

Nonprofit CO-CSA marketing methods included distributing flyers and posting announcements on social media and program and farm websites. Supportive partner organizations helped by spreading information through their networks. For example, participating Head Start centers and women's shel- 
Table 1. Characteristics of Cost-Offset Community Supported Agriculture (CO-CSA) Programs Operated by Nonprofits

\begin{tabular}{|c|c|c|c|c|c|}
\hline $\begin{array}{l}\text { Nonprofit } \\
\text { (Onset) }\end{array}$ & Cost offset & $\begin{array}{l}\text { CO-CSA weekly } \\
\text { cost (all in US\$) }\end{array}$ & $\begin{array}{c}\text { Shares sold, } \\
2018\end{array}$ & Eligibility & Other Accommodations \\
\hline $\begin{array}{l}\text { Nonprofit A } \\
(2009)\end{array}$ & $60 \% 40 \% 20 \%$ & $\begin{array}{l}\text { \$10 SNAP-EBT } \\
\text { \$15 Small Share } \\
\text { \$28 Large Share } \\
\$ 20 \text { Social Impact }\end{array}$ & 1,065 & $\begin{array}{l}\text { SNAP share for recipi- } \\
\text { ents only; others, self- } \\
\text { reported income }\end{array}$ & $\begin{array}{l}\text { - Weekly newsletter } \\
\text { - Cooking demonstrations } \\
\text { - Paper and online applications } \\
\text { in English and Spanish } \\
\text { - Spanish-speaking staff }\end{array}$ \\
\hline $\begin{array}{l}\text { Nonprofit B } \\
(2001)\end{array}$ & $\begin{array}{c}5 \%-10 \% 50 \% \\
100 \%\end{array}$ & $\begin{array}{l}\text { Sliding Scale: } \\
\text { \$15 Regular } \\
\text { \$28 Asylum- } \\
\text { seeker }\end{array}$ & 43 & $\begin{array}{l}\text { SNAP/EBT eligible, } \\
\text { according to self- } \\
\text { report }\end{array}$ & $\begin{array}{l}\text { - List of share contents emailed } \\
\text { in advance } \\
\text { - CSA recipe blog } \\
\text { - Formerly held nutrition classes }\end{array}$ \\
\hline $\begin{array}{l}\text { Nonprofit C } \\
(1992)\end{array}$ & $\begin{array}{l}50 \% \text { up to } \\
\text { US } \$ 300\end{array}$ & $\begin{array}{l}\text { Worker shares. } \\
\text { Offer extra large, } \\
\text { standard, small, } \\
\text { and custom sizes }\end{array}$ & 184 & $\begin{array}{l}\leq 185 \% \text { federal } \\
\text { poverty level as self- } \\
\text { reported }\end{array}$ & $\begin{array}{l}\text { - Cookbook } \\
\text { - Newsletters and recipes } \\
\text { - Custom swap, free choice, } \\
\text { market-style shares at some } \\
\text { farms }\end{array}$ \\
\hline $\begin{array}{l}\text { Nonprofit D } \\
(2007)\end{array}$ & $50 \%$ & $\begin{array}{l}\$ 25 \text { Full Share } \\
\$ 15 \text { Half Share } \\
\$ 15 \text { Fruit Share }\end{array}$ & 350 & SNAP/EBT users & $\begin{array}{l}\text { - Accessible pick-up sites Home } \\
\text { delivery } \\
\text { - Recipes in weekly box }\end{array}$ \\
\hline $\begin{array}{l}\text { Nonprofit E } \\
(2012)\end{array}$ & $75 \%$ & $\begin{array}{l}\text { \$5 Intervention } \\
\$ 20 \text { Market share }\end{array}$ & 79 & $\begin{array}{l}\text { Families with children } \\
\text { in Head Start }\end{array}$ & $\begin{array}{l}\text { - Culturally appropriate foods } \\
\text { included in share } \\
\text { - Familiar and convenient pick- } \\
\text { up sites and times } \\
\text { - Cooking demos } \\
\text { - Recipes and newsletters in } \\
\text { Spanish }\end{array}$ \\
\hline
\end{tabular}

Table 2. Funding Sources for Nonprofit Organizations with Cost-Offset Community Supported Agriculture (CO-CSA) Programs

\begin{tabular}{lllll}
\hline Organization & Grants & Donations & Government & Events \\
\hline Nonprofit A & $\begin{array}{l}\text { Private foundations } \\
\text { (primary source) }\end{array}$ & None mentioned & City council & None mentioned \\
\hline Nonprofit B & None mentioned & $\begin{array}{l}\text { Member donations } \\
\text { (primary source) }\end{array}$ & None mentioned & $\begin{array}{l}\text { Online fundraising } \\
\text { campaign }\end{array}$ \\
\hline Nonprofit C & Grants, a small amount & $\begin{array}{l}\text { Member and individual } \\
\text { donations }\end{array}$ & County funding & $\begin{array}{l}\text { Bike the Barns (primary } \\
\text { source) }\end{array}$ \\
\hline Nonprofit D & $\begin{array}{l}\text { CFDA and Market Match } \\
\text { via state agency }\end{array}$ & $\begin{array}{l}\text { Unrestricted from } \\
\text { individual donors }\end{array}$ & None mentioned & None mentioned \\
\hline Nonprofit E & Foundations & $\begin{array}{l}\text { Donors, restricted and } \\
\text { unrestricted }\end{array}$ & None mentioned & None mentioned \\
\hline
\end{tabular}

ters helped Nonprofit D conduct outreach and enroll families. Nonprofits B, C, and D said partners distributed materials at community events. Nonprofit $\mathrm{B}$ conducted informational presentations in selected workplaces, and Nonprofit C promoted the program during a CSA open house and a fundraising event. Nonprofit $C$ explicitly mentioned marketing through word of mouth, although it is likely that other programs also benefitted from this method. 


\section{Payment Transactions}

Nonprofits had various systems in place to accept and track weekly payments (Table 3).

\section{Facilitators to Successful CO-CSA Operation}

Strong and supportive relationships between nonprofits, their staff, and local partners, occurring in a community that values fresh local foods and equitable food access, were all key elements of successful CO-CSAs operated by nonprofit organizations.

Several nonprofits mentioned community support for local farmers and food as a factor contributing to their success. Nonprofit B described a vibrant local food culture in its northeastern city, with its large farmers market and food co-op. Nonprofit C similarly described enthusiasm for local foods in their midwestern city:

The term food system is known by almost everybody here. ... People get it, they're really tuned in. Local food is really strong and popular here. ... The [CO-CSA] program fits really well within that context. - Nonprofit $\mathrm{C}$

Appreciating locally grown foods was complemented by a community concern for social justice. Nonprofit C said local residents demonstrate this through a willingness to provide financial support to the CO-CSA, noting,

I think people understanding that if they can give more, then they should so that we can distribute that to the people who can't [pay]. So, like, people just don't really question the [US] $\$ 5$ delivery fee, knowing that the [US] $\$ 5$ delivery fee helps to offer free delivery for someone else. -Nonprofit D

Community values regarding food justice and locally produced foods extended to other social programs offered by the nonprofit. Nonprofit B's

Table 3. How Nonprofits with Cost-Offset Community Supported Agriculture (CO-CSA) Programs Handle Payment Transactions

\begin{tabular}{|c|c|c|c|c|}
\hline Nonprofit & $\begin{array}{l}\text { Payment } \\
\text { types }\end{array}$ & Accepting and recording payments & Payment plans and adjustments & Missed payments \\
\hline Nonprofit A & $\begin{array}{l}\text { Cash } \\
\text { Check } \\
\text { Debit } \\
\text { Credit } \\
\text { SNAP }\end{array}$ & $\begin{array}{l}\text { Farms use tablets to log pay- } \\
\text { ments onto Google spreadsheets. } \\
\text { Credit cards processed online. } \\
\text { Farms use EBT machine to } \\
\text { process SNAP payments. }\end{array}$ & $\begin{array}{l}\text { Payments made in advance on a } \\
\text { per week, monthly, or seasonal } \\
\text { basis. Members allowed to pause } \\
\text { and restart service. }\end{array}$ & $\begin{array}{l}\text { Weekly order can- } \\
\text { celed if payment } \\
\text { missed. }\end{array}$ \\
\hline Nonprofit B & $\begin{array}{l}\text { Cash } \\
\text { Check } \\
\text { Credit } \\
\text { SNAP }\end{array}$ & $\begin{array}{l}\text { Pick-up sites collect payments, } \\
\text { using Farmigo software to log } \\
\text { payments. SNAP/EBT payments } \\
\text { processed at central office. }\end{array}$ & $\begin{array}{l}\text { Weekly payments made at point } \\
\text { of sale (pick-up). }\end{array}$ & $\begin{array}{l}\text { Office negotiates } \\
\text { payment plan with } \\
\text { customers who miss. }\end{array}$ \\
\hline Nonprofit C & $\begin{array}{l}\text { Cash } \\
\text { Debit } \\
\text { Credit } \\
\text { SNAP }\end{array}$ & $\begin{array}{l}\text { Nonprofit C collects and tracks } \\
\text { payments on behalf of member } \\
\text { farms, using payment information } \\
\text { provided by shareholders and } \\
\text { kept on file. }\end{array}$ & $\begin{array}{l}\text { Monthly installment charged to } \\
\text { debit/ credit card, or a post-dated } \\
\text { check is cashed. SNAP paid via } \\
\text { EBT or by voucher. }\end{array}$ & $\begin{array}{l}\text { Happens infrequently } \\
\text { due to advance } \\
\text { payment required. }\end{array}$ \\
\hline Nonprofit D & $\begin{array}{l}\text { Cash } \\
\text { Check } \\
\text { PayPal } \\
\text { Credit } \\
\text { SNAP }\end{array}$ & $\begin{array}{l}\text { Pick-up sites collect payments, } \\
\text { using Farmiga software to log } \\
\text { payments. SNAP payments via } \\
\text { EBT machine at pick-up, or by } \\
\text { voucher for home deliveries. }\end{array}$ & $\begin{array}{l}\text { Payments made weekly at pick- } \\
\text { up or in advance. SNAP users } \\
\text { can get } 50 \% \text { discount if they pick } \\
\text { up at farmers market }\end{array}$ & $\begin{array}{l}\text { Customer alerted if } \\
\text { credit balance is } \\
\leq U S \$ 5 \text {. If a payment } \\
\text { is missed, no share is } \\
\text { prepared that week. }\end{array}$ \\
\hline Nonprofit E & $\begin{array}{l}\text { Cash } \\
\text { Check } \\
\text { SNAP }\end{array}$ & $\begin{array}{l}\text { Pick-up sites collected payments } \\
\text { and logged into Google } \\
\text { spreadsheet. }\end{array}$ & $\begin{array}{l}\text { Payments made weekly at pick- } \\
\text { up. Advance EBT for } 14 \text { day } \\
\text { period accepted }\end{array}$ & $\mathrm{n} / \mathrm{a}$ \\
\hline
\end{tabular}

* Nonprofit A processes SNAP vouchers, relaying information by telephone or an emailed photograph 
CO-CSA helps the nonprofit meet its goal of ensuring food security for immigrants while supporting agricultural economic development:

A lot of the cost-offset CSAs we offer are going to refugee families ... which I think reflects some of the demographic trends of [city], but also is specific to who our farmers are and who our community is. - Nonprofit B

Community confidence in the nonprofit was another facilitator, stemming from an organization's reputation for integrity, competence, and quality service.

[Success is due to] our community's attitude towards the work we do. I think a lot of people want transparency that we offer about our operation and the food system. And then just the values that dictate our work, like all of the money that we make really goes back into programming. $\quad$-Nonprofit D

I would say our mission and values really resonate with people, and also just providing quality service. $\quad$-Nonprofit A

Nonprofits credited the commitment of staff, volunteers, farmers, and community organizational partners, explaining that their dedication came from believing in the nonprofit's mission:

Everybody who's on our team wants to work with us because of our mission and values. ... [We] came from food-insecure households and so everyone is, I think, really deeply connected to the value of getting people food, especially the people who need it the most.

\section{—Nonprofit D}

Another nonprofit cited the values of participating farmers, who have a desire for everyone to enjoy the food they grow:

That manifests in terms of the farms being supportive and, you know, communicating about the program to potential CSA members and to members that might donate to the program. -Nonprofit $\mathrm{C}$

In addition to providing assistance with fundraising and weekly pick-ups, CO-CSAs were able to benefit from their partners' social capital. For example, Nonprofit B and Nonprofit E affirmed that partners' established relationships with LIHH facilitated recruitment and eased participant adjustment to the CO-CSA model:

I'd say that a strength of the model was ... there was somebody that families knew from the Head Start center that was helping get them engaged and excited about it.

-Nonprofit E

Media attention was an important facilitator. Nonprofit D described an uptick in demand following an article comparing their social enterprise to the business model of a for-profit competitor:

Our share numbers really skyrocketed after we published an article critiquing [competitor]that came out in the last week of August in 2018. ... The conversations that we are willing to have about the food system and that contributes to the success of our CSA.

-Nonprofit D

\section{Challenges to Successful CO-CSA Operation}

Nonprofits described a few challenges to success-

ful CO-CSA operation, mostly related to persistent barriers experienced by LIHH.

For example, weekly pick-up reportedly posed few problems, but accepting SNAP/EBT payments could be burdensome for both the CO-CSA and the customer:

I do think one of the biggest struggles we've had is having people have to come to our office to pay with their EBT/SNAP benefits, 'cause the USDA requires you to pay [with SNAP benefits] in person and you can't pay in advance, so people have to come once a month to our office, which is kind of a barrier to some folks. 
The lack of educational resources and cooking classes may have affected customer retention as some participants were uncertain how to use unfamiliar produce:

More so than having to go somewhere to pick up the bags, I think the bigger challenge is providing unfamiliar produce and not maybe as much support on what to do with that produce as some people may need. -Nonprofit B

The perceived inconvenience of the CSA model may have been another impediment to customer retention. Despite the lower cost and a convenient pick-up location, some LIHH appeared to prefer shopping at supermarkets, where they had choice and flexibility about the way they spend their limited food dollars, according to one interviewee:

People are interested in fresh food but would much prefer to get it in smaller quantities from stores. Like, we hear that from our very-highincome customers too. I think it just showed up sooner with low-income customers because they just don't have as much flexibility.

-Nonprofit E

Thus, even though CO-CSA members perceived the model to be affordable and convenient, many wanted more choice and flexibility in how they spent their limited food dollars. Ultimately, Nonprofit E discontinued the CO-CSA program and focused exclusively on providing fresh produce to LIHH through their work with farmers markets and small retailers.

\section{Advice on Operating a CO-CSA}

Both Nonprofit $C$ and Nonprofit $E$ recommended that new CO-CSA programs strive for simplicity when setting up administrative procedures, logistics, and systems for processing and tracking payments:

Just really, think through each of the pieces to start with and try to keep it as simple as possible. -Nonprofit C
Nonprofit D noted that creativity, flexibility, and a determination to do a lot with very little went a long way toward maintaining its social justice food program:

Be like self- and community-funded as much as possible, because, you know, a lot of grants don't wanna fund labor.... [Bank loans] have a lot stricter repayment rules than like getting your community to donate money towards your program when you need it. ... You can do it with very little and still get it done. And I think sometimes people get caught up in the waiting for the perfect moment and like you need all of the right equipment.

—Nonprofit D

Nonprofit $\mathrm{C}$ emphasized that calling on the power of community partners helped it promote the CO-CSA, advising that new programs

to not stand alone, to think about the program in the context of a community-'cause a lot of people have shared interest and a lot of people are really invested in healthy foods and ensuring folks have access to good, local veggies. -Nonprofit C

When asked to offer final thoughts on operating the CO-CSA program, Nonprofit A commented on the difficulty of balancing social values and the need to make a profit for farmers:

I think the challenge at the intersection of local food and food access is that truly meeting the needs of local farmers and low-income communities are in competition with each other and I think that's something that folks don't really talk about or think about, but it's a reality that needs to be addressed. -Nonprofit A

\section{LIHHs and CO-CSAs}

In closing, we asked respondents to share their reflections on what motivates LIHH to participate in their CO CSA program, receiving these comments:

We have these really great, nuanced conversations with people that really value it because 
their money is more limited and so they're really thinking about the program and what the vegetables will do for them in a really detailed sense. ... They wanna make sure that their kids have fresh, healthy, organic food. Or, they've heard from their doctor, they're facing a health issue and the doctor was like, eat clean, eat fresh, eat healthy, eat organic as much as possible. -Nonprofit C

[CO-CSA members] indicate a higher level of understanding of what a farmer faces in terms of difficulties and challenges ... Somebody who's having trouble making their payments, a lot of times they'll be like, 'you know, I'm really sorry and I especially feel really bad because I know farmers don't make a lot of money.'... So, there's definitely that strong interest in supporting the local economy and their local farmers. $\quad$-Nonprofit $\mathrm{C}$

However, not all members from LIHH participate because they embrace CSA values:

Generally, people are interested in fresh produce and for some people, they're also connecting it to the aspects of local agriculture and local economy. But, certainly not everybody. In fact, the sites that are in some of the highest peak areas, for them it's just about ... making sure that they have fresh produce where they often don't. - Nonprofit A

\section{Discussion}

CO-CSA programs have the potential to improve access to fresh, local FV for LIHH while simultaneously increasing farm revenues, but this model may be challenging for single farms to implement alone. Our interviews with five well-established CO-CSA programs illustrated several ways of administering a CO-CSA program: (1) providing direct subsidies to individual CO-CSA member farms; (2) functioning as an aggregator of regional produce, by packing and delivering shares themselves; and (3) sourcing from an in-house farm incubator or food hub, then packing and coordinating delivery to pick-up sites.

In previous studies, farmers have expressed concerns about the time, labor, and skills it would require to raise funds, recruit low-income members, and administer the CO-CSA going forward (Quandt et al., 2013; Sitaker et al., 2020b). Nonprofits are able to address these challenges through the infrastructure, resources, and staffing they are able to devote to operating the CO-CSA.

The nonprofit CO-CSA directors and managers we interviewed said collaborating with community partners helped facilitate outreach and recruitment. For some, community partners also supported the CO-CSA with ancillary programming such as nutrition education. Nonprofit directors and managers credited their CO-CSA's success to the dedication and competence of staff and partners who shared a common vision to make fresh, local produce more accessible to LIHH. Community enthusiasm for locally grown foods and support for the nonprofit's broader social justice mission were also identified as facilitators.

Respondents said many CO-CSA members appeared motivated to join by a desire to enhance their health and that of their families. Additionally, the ability of those living in food deserts to access fresh, local produce "at a good price" may have motivated them to participate. According to respondents, some CO-CSA members seemed committed to supporting farmers who grow their food. This may explain why few reported problems with timely pick-up and payment, a concern about CO-CSA that farmers had reported previously (Quandt et al., 2013; Sitaker et al., 2020b). However, nonprofit CO-CSA managers and directors may underreport problems with timely pick-up and payment because they had less direct experience with these activities, or because they sometimes rely on farmers to manage distribution and payment transactions.

A comparison of CO-CSAs operated by nonprofit organizations and single farms deserves further investigation, particularly with regard to customer retention, operational efficiencies, relative effectiveness, cost-benefit ratios, and impacts on farm profitability. While nonprofit CO-CSAs have the advantage of having designated staffing, resources, and expertise, they may still struggle to allocate these resources to balance the twin goals of maximizing food security for LIHHs and support- 
ing the economic viability of local farms. Research aimed at explicating the advantages and challenges of organization-led CO-CSAs compared to singlefarm CO-CSAs is needed to inform policies and practices that can increase access to fresh, local produce for LIHH while providing equitable returns to farms.

\section{Limitations}

The interviews with managers and directors from five nonprofit CO-CSAs provide a useful description of the characteristics and operations across geographically diverse programs. However, none was identified in the southeast region of the U.S. Findings from this purposive sample cannot be generalized to all CO-CSAs operated by nonprofits. Further, this analysis would have been enhanced by the addition of a diverse array of perspectives from other staff and partners engaged in CO-CSA operations. Gathering and examining quantitative data on the costs of operation, revenue, and profitability were beyond the scope of this study and thereby limited our conclusions about the economics of nonprofit CO-CSA programs.

\section{Conclusions}

CO-CSAs are a potential solution to limitations in access to fresh, local produce for LIHH and may also expand markets for CSA farmers. Nonprofit organizations have dedicated staff and resources to operate the CO-CSA programs, and therefore may be better able to handle the required fund-raising, recruitment, and administration than single farms, whose priority is running their farm business. This study of five nonprofits with established CO-CSAs adds to our knowledge of nonprofit CO-CSA programs and illustrates the diversity of approaches used to organize, source, and aggregate produce, and to pack and distribute CO-CSA shares on a large scale. CO-CSAs operated by nonprofits relied on grants and local government funding to support their operations. Future research should examine the relative merits of CO-CSAs led by nonprofits compared to those operated by single farms to implement the models more broadly and stimulate federal grant support for CO-CSA.

\section{Acknowledgments}

We would like to acknowledge the contributions and efforts of our colleague Olivia Chitwood, as well as all extension, farmer, agricultural coaches, and educator partners who have contributed their time and expertise to the Farm Fresh Foods for Healthy Kids study.

\section{References}

Abbott, C. (2014). Evaluation of the Food Bank of Delaware community supported agriculture program (Doctoral dissertation), University of Delaware. http://udspace.udel.edu/handle/19716/15588

Allen IV, J. E., Rossi, J., Woods, T. A., \& Davis, A. F. (2017). Do community supported agriculture programmes encourage change to food lifestyle behaviours and health outcomes? New evidence from shareholders. International Journal of Agricultural Sustainability, 15(1), 70-82. https://doi.org/10.1080/14735903.2016.1177866

Andreatta, S., Rhyne, M., \& Dery, N. (2008). Lessons learned from advocating CSAs for low-income and food insecure households. Southern Rural Sociology, 23(1), Article 6. https://egrove.olemiss.edu/jrss/vol23/iss1/6

Aune, D., Giovannucci, E., Boffetta, P., Fadnes, L. T., Keum, N., Norat, T., Greenwood, D. C., Riboli, E., Vatten, L. J., \& Tonstad, S. (2017). Fruit and vegetable intake and the risk of cardiovascular disease, total cancer and all-cause mortality-A systematic review and dose-response meta-analysis of prospective studies. International Journal of Epidemiology, 46(3), 1029-1056. https://doi.org/10.1093/ije/dyw319

Calancie, L., Leeman, J., Pitts, S. B. J., Khan, L. K., Fleischhacker, S., Evenson, K. R., Schreiner, M., Byker, C., Owens, C., McGuirt, J., Barnidge, E., Dean, W., Johnson, D., Kolodinsky, J., Piltch, E., Pinard, C., Quinn, E., Whetstone, L., \& Ammerman, A. (2015). Nutrition-related policy and environmental strategies to prevent obesity in rural communities: A systematic review of the literature, 2002-2013. Preventing Chronic Disease, 12, Article 140540. https://doi.org/10.5888/pcd12.140540

Carter, P., Gray, L. J., Troughton, J., Khunti, K., \& Davies, M. J. (2010). Fruit and vegetable intake and incidence of type 2 diabetes mellitus: Systematic review and meta-analysis. British Medical Journal (Clinical Research Ed.), 341, Article c4229. https://doi.org/10.1136/bmj.c4229 
Cohen, N., \& Derryk, D. (2011). Corbin Hill Road Farm Share: A hybrid food value chain in practice. Journal of Agriculture, Food Systems and Community Development, 1(4), 85-100. https://doi.org/10.5304/jafscd.2011.014.011

Dimitri, C., Oberholtzer, L., Zive, M., \& Sadolo, C. (2015). Enhancing food security of low-income consumers: An investigation of financial incentives for use at farmers markets. Food Policy, 52, 64-70. https://doi.org/10.1016/i.foodpol.2014.06.002

Durward, C. M., Savoie-Roskos, M., Atoloye, A., Isabella, P., Jewkes, M. D., Ralls, B., Riggs, K., \& LeBlanc, H. (2019). Double Up Food Bucks participation is associated with increased fruit and vegetable consumption and food security among low-income adults. Journal of Nutrition Education and Behavior, 51(3), 342-347. https://doi.org/10.1016/i.jneb.2018.08.011

Forbes, C. B., \& Harmon, A. H. (2008). Buying into community supported agriculture: Strategies for overcoming income barriers. Journal of Hunger \& Environmental Nutrition, 2(2-3), 65-79. https://doi.org/10.1080/19320240801891479

Galt, R. E., Bradley, K., Christensen, L., Fake, C., Munden-Dixon, K., Simpson, N., Surls, R., \& Kim, J. V. S. (2017). What difference does income make for Community Supported Agriculture (CSA) members in California? Comparing lower-income and higher-income households. Agriculture and Human V alues, 34, 435-452. https://doi.org/10.1007/s10460-016-9724-1

Grimm, K. A., Foltz, J. L., Blanck, H. M., \& Scanlon, K. S. (2012). Household income disparities in fruit and vegetable consumption by state and territory: Results of the 2009 Behavioral Risk Factor Surveillance System. Journal of the Academy of Nutrition and Dietetics, 112(12), 2014-2021. https://doi.org/10.1016/j.jand.2012.08.030

Guthman, J., Morris, A. W., \& Allen, P. (2006). Squaring farm security and food security in two types of alternative food institutions. Rural Sociology, 71(4), 662. https://doi.org/10.1526/003601106781262034

Hoffman, J. A., Agrawal, T., Wirth, C., Watts, C., Adeduntan, G., Myles, L., \& Castaneda-Sceppa, C. (2012). Farm to family: Increasing access to affordable fruits and vegetables among urban head start families. Journal of Hunger \& Environmental Nutrition, 7(2-3), 165-177. https://doi.org/10.1080/19320248.2012.703522

Kamphuis, C. B., Giskes, K., de Bruijn, G., Wendel-Vos, W., Brug, J., \& Van Lenthe, F. J. (2006). Environmental determinants of fruit and vegetable consumption among adults: A systematic review. British Journal of Nutrition, 96(04), 620-635. https://doi.org/10.1079/BJN20061896

Khan, L. K. K. K., Sobush, K., Keener, D., Goodman, K., Lowry, A., Kakietek, J., \& Zaro, S. (2009, July 24). Recommended community strategies and measurements to prevent obesity in the United States. Centers for Disease Control and Prevention. https://www.cdc.gov/mmwr/preview/mmwrhtml/rr5807a1.htm

Krebs-Smith, S. M., Guenther, P. M., Subar, A. F., Kirkpatrick, S. I., \& Dodd, K. W. (2010). Americans do not meet federal dietary recommendations. The Journal of Nutrition, 140(10), 1832-1838. https://doi.org/10.3945/jn.110.124826

Low, S. A., \& Vogel, S. J. (2011). Direct and intermediated marketing of local foods in the United States (U.S. Department of Agriculture Economic Research Report No. 128). https://doi.org/10.2139/ssrn.2114361

Minaker, L. M., Raine, K. D., Fisher, P., Thompson, M. E., Van Loon, J., \& Frank, L. D. (2014). Food purchasing from farmers' markets and community-supported agriculture is associated with reduced weight and better diets in a population-based sample. Journal of Hunger \& Environmental Nutrition, 9(4), 485-497. https://doi.org/10.1080/19320248.2014.898175

Moore, L. V., Dodd, K. W., Thompson, F. E., Grimm, K. A., Kim, S. A., \& Scanlon, K. S. (2015). Using behavioral risk factor surveillance system data to estimate the percentage of the population meeting US department of agriculture food patterns fruit and vegetable intake recommendations. American Journal of Epidemiology, 181(12), 979-988. https://doi.org/10.1093/aje/kwu461

Olsho, L. E., Payne, G. H., Walker, D. K., Baronberg, S., Jernigan, J., Abrami, A. (2015). Impacts of a farmers' market incentive programme on fruit and vegetable access, purchase and consumption. Public Health Nutrition, 18, 27122721. https://doi.org/10.1017/s1368980015001056 
Quandt, S. A., Dupuis, J., Fish, C., \& D’Agostino Jr, R. B. (2013). Feasibility of using a community-supported agriculture program to improve fruit and vegetable inventories and consumption in an underresourced urban community. Preventing Chronic Disease, 10, Article 130053. https://doi.org/10.5888/pcd10.130053

Seguin-Fowler, R., Ammerman, A., Hanson, K., Pitts, S. J., Kolodinsky, J., Marshall, G., Morgan, E., Sitaker, M., \& Wang, W. (2020). Cost-offset community supported agriculture plus nutrition education improves household food security and fruit and vegetable intake among adult caregivers but not children: A randomized controlled trial [Poster abstract]. Journal of Nutrition Education and Behavior, 52(7), S86. http://doi.org/10.1016/j.jneb.2020.04.194

Sitaker, M., McGuirt, J. T., Wang, W., Kolodinsky, J., \& Seguin, R. A. (2019). Spatial considerations for implementing two direct-to-consumer food models in two states. Sustainability, 11(7), 2081. https://doi.org/10.3390/su11072081

Sitaker, M., McCall, M., Belarmino, E., Wang, W., Kolodinsky, J., McGuirt, J. T., Jilcott Pitts, S. B., \& Seguin-Fowler, R. A. (2020a). Balancing social values with economic realities. Journal of Agriculture, Food Systems, and Community Development, 9(4), 29-43. https://doi.org/10.5304/jafscd.2020.094.004

Sitaker, M., McCall, M., Kolodinsky, J., Wang, W., Ammerman, A., Bulpitt, K., Jilcott Pitts, S. B., Hanson, K., Volpe, L. C., \& Seguin-Fowler, R. A. (2020b). Helping farmers with continuation planning for cost-offset community supported agriculture to low-income families. Journal of Agriculture, Food Systems, and Community Development, 9(4), 93-112. https://doi.org/10.5304/jafscd.2020.094.037

Sitaker, M., McCall, M., Vaccaro, M., Wang, W., Kolodinsky, J., Pitts, S. J., Hanson, K., Volpe, L. C., \& Seguin-Fowler, R. (2020c). Cost offset community supported agriculture in the United States: An environmental scan. (Unpublished manuscript).

U.S. Department of Agriculture Agricultural Marketing Service [USDA AMS]. (2016). Farmers market promotion program 2016 report. https://www.ams.usda.gov/sites/default/files/media/FMPP2016Report.pdf

Vasquez, A., Sherwood, N. E., Larson, N., \& Story, M. (2016). A novel dietary improvement strategy: Examining the potential impact of community-supported agriculture membership. Public Health Nutrition, 19(14), $2618-2628$. https://doi.org/10.1017/S1368980015003638

Wang, X., Ouyang, Y., Liu, J., Zhu, M., Zhao, G., Bao, W., \& Hu, F. B. (2014). Fruit and vegetable consumption and mortality from all causes, cardiovascular disease, and cancer: Systematic review and dose-response meta-analysis of prospective cohort studies. British Medical Journal, 349, Article g4490. https://doi.org/10.1136/bmj.g4490

Wilson, M. M., Reedy, J., \& Krebs-Smith, S. M. (2016). American diet quality: Where it is, where it is heading, and what it could be. Journal of the Academy of Nutrition and Dietetics, 116(2), 302-310, Article e1. https://doi.org/10.1016/j.jand.2015.09.020

Woods, T., Ernst, M., \& Tropp, D. (2017). Community supported agriculture: New models for changing markets. U.S. Department of Agriculture, Agricultural Marketing Service. https://www.ams.usda.gov/publications/content/community-supported-agriculture-new-models-changing-markets

Young, C. R., Aquilante, J. L., Solomon, S., Colby, L., Kawinzi, M. A., Uy, N., \& Mallya, G. (2013). Improving fruit and vegetable consumption among low-income customers at farmers markets: Philly Food Bucks, Philadelphia, Pennsylvania, 2011. Preventing Chronic Disease, 10, Article E166. https://doi.org/10.5888/pcd10.120356 


\section{Appendix A. Interview Guide for CO-CSA Programs Operated by Nonprofit Organizations}

\section{Demographics:}

Name of organization:

Name of contact person:

Address:

Email:

Phone:

Website:

First, l'd like to hear about your organization.

1. How would you describe your organization? [PROBE: would you describe it as a food hub? state agency? nonprofit? etc.]

a. Is your $\mathrm{CO}$ a stand-alone organization or a program of a parent organization?

b. How long has the $\mathrm{CO}$ program been in operation?

c. What other services does your organization offer?

Next, l'd like to hear how your cost offset program operates.

Let's start with participating farms.

2. Tell me about the farms that currently participate in the CO CSA.
a. How many are there?
b. About how long have they participated in the CO CSA?
c. What is the geographic "spread" of these farms (e.g., within a $5 \mathrm{mi}, 10 \mathrm{mi}$ or $25 \mathrm{mi}$ radius, etc.)?

3. How do new farms usually get involved with your CO CSA program?

Next, l'd like to ask about participating CO-CSA members.

4. How many CO-CSA shares did your organization subsidize in 2018 ?
a. How does this compare to past seasons?
b. How many are repeat members? (Note, this may only be known to participating farmers)

5. What are the eligibility criteria for CO-CSA membership?
a. Is it the same for all farms?
b. Who sets the criteria and applies it?

6. How do potential CO CSA members hear about the program?

[PROBE: What outreach/marketing activities are conducted to inform low-resource consumers about the $\mathrm{CO}$ ? who is responsible for this work?]

Now, we will more on to CO-CSA operations.

7. Who is the key decision maker (the organization or the farmer(s)) regarding:
a. CSA share sizes (e.g., regular and half shares) and prices
b. Percent of the market share price that is cost-offset
c. What goes into each weekly share? [PROBE: Do you tell farmers what to grow, or do they make this choice themselves?]


8. Tell me about how CO-CSA shares are packed and delivered each week. [PROBE: Do farmers deliver food to a central location, which your organization subsequently packs and delivers to pick-up sites? Or, do participating farms handle some or all that?]

9. Tell me about how CO-CSA pick-up sites and how they're selected (PROBE: Is there a central pick-up location for CO-CSAs from multiple farms? Does each farm have its own pick-up site(s)?)

10. Who collects installment payments? [PROBE: How are missed payments handled?] (What system do you use to streamline this administrative task?)

11. Do you offer any other ways that make it easier for low-income families to purchase CSA shares?

[PROBE: "For example, do you offer..."]

- Installment payment plans

- Accepting SNAP/EBT

- Choosing accessible sites for CO-CSA pick-up

- Tailoring box items to meet preferences of low-income families

- Allowing market-style selection of items

- Weekly box includes simple recipes

- Newsletters with tailored tips and advice

- Referral to nutrition education programming

- Other

Now l'd like to hear about your community partnerships.

12. What community partners help you with CO-CSA?

[Probe: For example, local nonprofits, Extension, colleges, religious organizations, and businesses]

13. What roles do these partners play?

[PROBE: For example, do they provide....

- a convenient pick-up site location for your low-income community members

- transportation to a pick-up site

- $\quad$ assistance with share pick-ups or administrative support (i.e. bank accounts, EBT equipment, farmer reimbursements)

- market assessment or other data collection and analysis

- outreach support, such as identifying and enrolling CO-CSA members, or translation of outreach materials

14. Finally, l'd like to know more about the fundraising you do to support your CO-CSA program.

a. Tell me about your funding sources

[Prompt: do you have grants from state agencies; foundations, businesses; fundraising events; social enterprises that generate funds, other?]

b. Roughly speaking, what is your annual fundraising goal?

c. Do any of your local partners help with local fundraising? If so, who are they and what are their roles?

d. Are participating farms also responsible for raising/contributing funds for the CO-CSA? If yes, what proportion?

I have just a couple more questions to wrap things up.

15. Can you identify any unique characteristics of your organization that contribute to the success of your COCSA? Are there any aspects of your local context-public attitudes, lack of other local food outlets, etc.that make it easier to operate a CO-CSA?

16. What advice would you give to other organizations who want to develop an organization program like yours? 
Appendix B. Logistics

Table B1. Logistical Arrangements of Five Nonprofit CO-CSAs

\begin{tabular}{|c|c|c|c|c|c|}
\hline Topic & Nonprofit A & Nonprofit B & Nonprofit C & Nonprofit D & Nonprofit E \\
\hline $\begin{array}{l}\text { Role of the } \\
\text { nonprofit }\end{array}$ & $\begin{array}{l}\text { Previously, worked directly } \\
\text { with farms but began } \\
\text { working with } 4 \text { food hubs } \\
\text { in } 2016 \text {. Additionally, } \\
\text { Nonprofit A provides train- } \\
\text { ing, tools, supplies, and } \\
\text { technical support to } \\
\text { manage pick-ups and } \\
\text { collect payments. }\end{array}$ & $\begin{array}{l}\text { The CO-CSA program is } \\
\text { self-contained; all CO-CSA } \\
\text { functions are managed } \\
\text { and handled by Nonprofit } \\
\text { B. }\end{array}$ & $\begin{array}{l}44 \text { farms with CO-CSAs in } \\
\text { the Nonprofit C Coalition } \\
\text { receive a cost-offset. } \\
\text { Nonprofit C manages } \\
\text { customers' monthly } \\
\text { installment payments and } \\
\text { then forwards them to } \\
\text { each farm. }\end{array}$ & $\begin{array}{l}\text { Nonprofit D functions as a } \\
\text { food hub, buying produce } \\
\text { from local farms. } \\
\text { Nonprofit D selects items } \\
\text { from a producer- } \\
\text { generated list of available } \\
\text { products to include each } \\
\text { week. }\end{array}$ & $\begin{array}{l}\text { For its CO-CSA program, } \\
\text { Nonprofit E worked with } \\
\text { farms in its training program. } \\
\text { It coordinated with Head } \\
\text { Start to recruit participants } \\
\text { and serve as pick-up sites. }\end{array}$ \\
\hline $\begin{array}{l}\text { Setting price } \\
\text { and cost-offset } \\
\text { amount }\end{array}$ & $\begin{array}{l}\text { Each food hub sets prices } \\
\text { for various items; } \\
\text { Nonprofit A selects items } \\
\text { to purchase, based on } \\
\text { price and availability. }\end{array}$ & $\begin{array}{l}\text { The food hub determines } \\
\text { share cost and cost-offset } \\
\text { parameters, and selects } \\
\text { items for the weekly share } \\
\text { in consultation with its } \\
\text { member farms. }\end{array}$ & $\begin{array}{l}\text { Nonprofit } C \text { sets cost- } \\
\text { offset parameters } \\
\text { (amount and cap). Each } \\
\text { farm decides what to grow } \\
\text { and determines share } \\
\text { sizes and pricing. }\end{array}$ & $\begin{array}{l}\text { Nonprofit D sets the cost- } \\
\text { offset parameters, and } \\
\text { growers set prices. }\end{array}$ & $\begin{array}{l}\text { The Nonprofit E CO-CSA } \\
\text { coordinator made decisions } \\
\text { in collaboration with } \\
\text { participating farms about } \\
\text { share sizes and pricing. }\end{array}$ \\
\hline $\begin{array}{l}\text { Where food is } \\
\text { sourced }\end{array}$ & $\begin{array}{l}\text { Since } 2016 \text {, Nonprofit A } \\
\text { has contracted with } 4 \\
\text { food hubs that aggregate } \\
\text { food from over } 200 \\
\text { growers, mainly from NY } \\
\text { and NJ, but as far south } \\
\text { as PA and as far north as } \\
\text { ME. }\end{array}$ & $\begin{array}{l}\text { The nonprofit runs two } \\
\text { training/ incubation farms } \\
\text { within a } 45-\text { mile radius of } \\
\text { Portland, ME, that provide } \\
\text { food. }\end{array}$ & $\begin{array}{l}44 \text { member farms are } \\
\text { mostly in southern } \\
\text { Wisconsin, with some } \\
\text { elsewhere in WI and one } \\
\text { in MN. }\end{array}$ & $\begin{array}{l}\text { Five farms owned by a } \\
\text { person of color, and } 2 \\
\text { honey producers, all } \\
\text { within } 70 \text { miles of } \\
\text { Oakland. Farms deliver to } \\
\text { Nonprofit D's North } \\
\text { Oakland office. }\end{array}$ & $\begin{array}{l}5 \text { farms ranging in size from } \\
30 \text { acres to a half-acre, } \\
\text { located in suburban, urban } \\
\text { and agricultural } \\
\text { conservation lands. }\end{array}$ \\
\hline $\begin{array}{l}\text { How food is } \\
\text { delivered }\end{array}$ & $\begin{array}{l}\text { Produce is delivered to } 23 \\
\text { CSA market-style pick-up } \\
\text { sites in health clinics, } \\
\text { colleges, senior centers, } \\
\text { churches, housing } \\
\text { developments, and city } \\
\text { agencies. Pick-up is } \\
\text { managed by volunteers } \\
\text { and consumers assemble } \\
\text { their own boxes. }\end{array}$ & $\begin{array}{l}\text { Farmers pack and deliver } \\
\text { the CO-CSA shares to } \\
\text { participating pick-up sites, } \\
\text { located in public places } \\
\text { such as the YMCA, } \\
\text { breweries, and work sites } \\
\text { with at least } 10 \text { employee } \\
\text { shareholders. }\end{array}$ & $\begin{array}{l}\text { Farms pack and deliver } \\
\text { CO-CSA shares to pick-up } \\
\text { sites of their own } \\
\text { choosing. }\end{array}$ & $\begin{array}{l}\text { The nonprofit aggregates } \\
\text { and packs weekly CSAs, } \\
\text { then dispatches delivery } \\
\text { drivers to pick-up sites, } \\
\text { located at volunteers' } \\
\text { homes. Sites are chosen } \\
\text { based on accessibility, } \\
\text { visibility, and theft } \\
\text { prevention. }\end{array}$ & $\begin{array}{l}\text { Farmers packed the weekly } \\
\text { shares and delivered them } \\
\text { to Nonprofit E's office, for } \\
\text { subsequent delivery by the } \\
\text { coordinator to pick-up sites } \\
\text { at five Head Start locations } \\
\text { and a women's shelter } \\
\text { daycare. In the final year of } \\
\text { CO-CSA operation, farms } \\
\text { delivered weekly shares } \\
\text { directly to the pick-up sites. }\end{array}$ \\
\hline
\end{tabular}

